\title{
Skrining Fitokimia Ekstrak Daun Jeruk Lemon (Citrus limon L.) dari Kota Langsa, Aceh
}

\author{
Irwan Saputra Harahap ${ }^{1}$, Halimatussakdiah ${ }^{1 *}$, dan Ulil Amna ${ }^{1}$ \\ ${ }^{1}$ Program Studi Kimia Fakultas Teknik Universitas Samudra \\ Jl. Meurandeh, Langsa Aceh 24416, Indonesia \\ *Corresponding author: halimatussakdiah@unsam.ac.id
}

\begin{abstract}
ABSTRAK
Telah dilakukan skrining fitokimia pada daun jeruk lemon. Jeruk lemon (Citrus limon L.) merupakan suatu tumbuhan yang sering dimanfaatkan oleh masyarakat terutama bagian buahnya. Untuk mengetahui kandungan kimianya, maka dilakukan uji keberadaan senyawa metabolit sekunder di dalam ekstrak daun jeruk lemon (Citrus limon L.). Daun jeruk lemon memiliki kandungan limonen yang dapat digunakan dalam terapi anti kanker. Ekstrak daun jeruk lemon diperoleh dengan menggunakan metode maserasi. Setelah ekstrak kasar daun jeruk lemon diperoleh, maka diuji kandungan senyawa fitokimianya secara kualitatif. Berdasarkan uji fitokimia yang dilakukan maka diketahui bahwa ekstrak daun jeruk lemon positif mengandung golongan senyawa alkaloid, flavonoid, fenol, dan tanin.
\end{abstract}

Kata Kunci: Alkaloid, Ekstraksi, Fenol, Fitokimia, Flavonoid, Tanin.

\section{PENDAHULUAN}

Indonesia merupakan salah satu negara yang memiliki keanekaragaman hayati yang sangat melimpah. Hal ini disebabkan oleh iklim dan kondisi geografis yang sangat mendukung pertumbuhan dari tumbuhan tersebut [1], [2].

Tumbuhan memiliki peran yang sangat penting bagi kehidupan manusia, maka pengetahuan mengenai aktivitas biologis yang ditimbulkan oleh senyawa yang terkandung dalam tumbuhan sangat diperlukan untuk menemukan sumber obat terbaru dari suatu penyakit [3]. Salah satu tumbuhan yang diyakini berpotensi untuk dikembangkan menjadi obat adalah jeruk lemon (Citrus limon L.).

Klasifikasi tanaman jeruk lemon adalah sebagai berikut:

$\begin{array}{ll}\text { Kingdom } & \text { : Plantae } \\ \text { Divisi } & : \text { Magnoliophyta } \\ \text { Kelas } & : \text { Rosidae } \\ \text { Ordo } & : \text { Sapindales } \\ \text { Family } & : \text { Rutaceae } \\ \text { Marga } & : \text { Citrus } \\ \text { Jenis } & : \text { Citrus limon (L.) }\end{array}$

Tumbuhan lemon merupakan perdu atau pohon yang daunnya berbentuk oval, sayap daun sempit/marginal, warna bunganya kemerahan disertai dengan stamens yang banyak, buahnya berwarna kuning dengan bentuk membundar (panjang 8-9 cm), kulitnya kasar dan rasanya asam, bijinya kecil dengan bentuk ovoid, serta permukan biji yang halus [4], [5]. Lemon mengandung berbagi senyawa kimia penting yang dapat dimanfaatkan dalam dunia kesehatan. Senyawa yang terkandung dalam lemon antara lain asam sitrat, asam askorbat, mineral, dan flavonoid [6], [7].

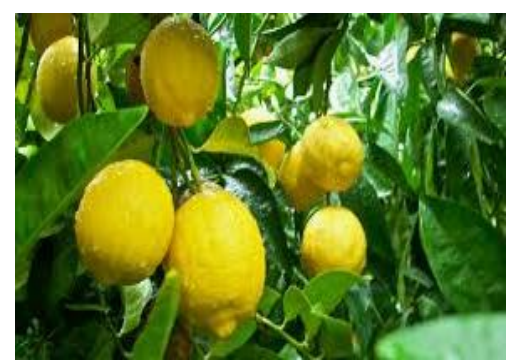

Gambar 1. Foto tanaman jeruk lemon (Citrus limon L.)

Aktivitas biologis yang dimiliki oleh tumbuhan jeruk lemon ini disebabkan karena adanya kandungan senyawa metabolit sekunder yang terdapat didalamnya [8]. Selain buahnya, bagian tanaman jeruk lemon yang memiliki potensi bioaktivitas yang tinggi adalah bagian daun, daun jeruk lemon memiliki kandungan limonen, tanin dan fenol yang bermanfaat untuk kesehatan seperti mengatasi penyakit kanker, jantung dan liver [9]. Penelitian sebelumnya melaporkan bahwa ekstrak metanol daun jeruk 
lemon mengandung senyawa alkaloid, flavonoid, steroid/triterpenoid, tanin dan minyak atsiri [10].

Ekstraksi merupakan suatu proses pemisahan dari bahan padat maupun cair dengan bantuan suatu pelarut. Pelarut yang digunakan harus dapat mengekstrak substansi yang diinginkan tanpa melarutkan material lainnya. Ekstraksi menggunakan pelarut didasarkan pada kelarutan komponen terhadap komponen lain dalam campuran [11]. Dalam mengekstrak suatu sampel, harus diperhatikan tolak ukur kualitas simplisia terlebih dahulu.

Tolak ukur dari kualitas simplisia meliputi susut pengeringan, kadar air, kadar abu, kadar abu tidak larut asam, kadar sari larut air, kadar sari larut etanol, serta dapat juga dilakukan pemeriksan organoleptik mikroskopis dan makroskopis sebagai data pelengkap [10]. Bagian tumbuhan yang digunakan dalam penelitian ini adalah daun. Penelitian yang menganalisis kandungan senyawa metabolit sekunder dalam tumbuhan jeruk lemon dari daerah Aceh belum banyak dilakukan. Hal ini yang melatarbelakangi dilakukannya penelitian awal untuk mengidentifikasi golongan senyawa metabolit sekunder yang terkandung di dalam sampel daun jeruk lemon.

\section{BAHAN DAN METODE}

\section{Bahan}

Bahan yang digunakan adalah sampel daun jeruk lemon kering dan sampel daun jeruk lemon segar, aquades, metanol, $n$-heksana, etil asetat, asam sulfat, besi (III) klorida, pereaksi wagner, pereaksi meyer, pereaksi dragendorf.

\section{Alat}

Alat yang digunakan adalah kertas saring whattman, hot plate, rak tabung reaksi, tabung reaksi, corong pisah, erlenmeyer dan pipet tetes.

\section{Metode}

\section{a. Preparasi Sampel}

Daun jeruk lemon sebanyak $10 \mathrm{~g}$ diambil di Desa Meurandeh, kecamatan Langsa Lama, Kota Langsa, provinsi Aceh. Daun jeruk lemon terlebih dahulu dikeringanginkan, setelah kering dihaluskan hingga diperoleh serbuk kering yang kemudian akan diekstraksi. Selain itu, sampel juga diambil tanpa dilanjutkan proses pengeringan sebagai perbandingan antara sampel daun segar dan daun kering.

\section{b. Ekstraksi}

Daun segar dan daun kering jeruk lemon sebanyak $10 \mathrm{~g}$ dihaluskan dan diekstraksi menggunakan metanol dengan metode maserasi selama $3 \times 24$ jam, proses maserasi diulang secara terus-menerus sampai filtratnya tidak berwarna lagi. Filtrat yang diperoleh kemudian disaring dan diuapkan dengan rotary evaporator untuk menghasilkan ekstrak kasar metanol [12].

\section{c. Uji alkaloid}

Ekstrak metanol ditambahkan $1 \mathrm{~mL}$ amonia. Selanjutnya ditambahkan $10 \mathrm{~mL}$ kloroform, kemudian disaring. Filtrat yang diperoleh kemudian ditambahkan $10 \mathrm{~mL}$ asam sulfat $2 \mathrm{~N}$, dikocok kuat-kuat, dibiarkan selama satu menit sampai larutan asam sulfat dan kloroform memisah. Lapisan asam sulfat diambil dan dibagi kedalam tiga buah tabung reaksi. Masingmasing tabung reaksi diuji dengan pereaksi Meyer, Dragendorff, dan Wagner untuk menentukan keberadaan alkaloid. Penambahan reagen Meyer membentuk endapan putih, reagen Dragendorff menghasilkan endapan kemerahan, dan reagen Wagner menghasilkan endapan kuning. Hasil tersebut menunjukkan positif mengandung golongan senyawa alkaloid [12].

\section{d. Uji Terpenoid, Steroid, dan Saponin}

Ekstrak metanol dipartisi dengan $n$-heksana. Ekstrak yang larut dalam $n$-heksana diuji dengan reagen Liberman-Bourchard. Terbentuknya warna biru atau hijau menunjukkan adanya steroid dan warna merah untuk terpenoid. Residu yang tidak larut dalam $n$-heksana ditambahkan air dan diguncang dengan kuat. Apabila terbentuk busa yang stabil selama 30 menit menunjukkan adanya saponin, jika positif untuk saponin, larutan dihidrolisis dengan $\mathrm{HCl}$ dan diuji dengan pereaksi Liberman-Bourchard. Warna hijau atau biru menunjukkan adanya saponin steroid dan warna ungu atau merah menunjukkan adanya saponin terpenoid [12]. 


\section{e. Uji Flavonoid}

Ekstrak metanol pekat dipartisi dengan nheksana. Kemudian residu diekstraksi dengan $10 \mathrm{~mL}$ etanol $80 \%$, selanjutnya ditambah $0,5 \mathrm{mg}$ logam magnesium dan $\mathrm{HCl}$ 0,5 M. Terbentuknya warna merah muda atau ungu menunjukkan adanya flavonoid [12].

\section{f. Uji Fenol}

Ekstrak metanol diuji dengan $\mathrm{FeCl}_{3}$. Sampel ditambahkan 3 - 4 tetes larutan $\mathrm{FeCl}_{3}$, pembentukan warna biru kehitaman menunjukkan senyawa fenol [12].

\section{g. Uji Tanin}

Ekstrak metanol dididihkan dalam $10 \mathrm{~mL}$ air dalam tabung reaksi dan kemudian disaring. Selanjutnya ditambahkan beberapa tetes Besi (III) klorida $\left(\mathrm{FeCl}_{3}\right)$ 0,1\% lalu diamati, jika terjadi perubahan warna hijau kecoklatan atau biru kehitaman menunjukkan adanya senyawa tanin [12].

\section{HASIL DAN PEMBAHASAN}

Daun jeruk lemon diekstraksi dengan metanol karena pelarut ini sangat baik dalam melarutkan senyawa metabolit sekunder dari sumbernya [5]. Hasil uji fitokimia disajikan pada Tabel 1.

Tabel 1. Hasil uji fitokimia ekstrak daun jeruk lemon (Citrus limon L.)

\begin{tabular}{clcc}
\hline No. & \multicolumn{1}{c}{$\begin{array}{c}\text { Metabolit } \\
\text { Sekunder }\end{array}$} & $\begin{array}{c}\text { Daun } \\
\text { Kering }\end{array}$ & $\begin{array}{c}\text { Daun } \\
\text { Segar }\end{array}$ \\
\hline Alkaloid & & \\
1. & - Dragendorff & $\checkmark$ & $\checkmark$ \\
& - Meyer & $x$ & $x$ \\
& - Wagner & $\checkmark$ & $\checkmark$ \\
2. & Terpenoid & $x$ & $x$ \\
3. & Steroid & $x$ & $x$ \\
4. & Saponin & $x$ & $x$ \\
5. & Flavonoid & $x$ & $\checkmark$ \\
6. & Fenol & $\checkmark$ & $\checkmark$ \\
7. & Tanin & $\checkmark$ & $\checkmark$ \\
\hline
\end{tabular}

$\checkmark \quad$ : Mengandung senyawa

$x \quad$ : Tidak mengandung senyawa

Uji fitokimia merupakan suatu pengujian yang bertujuan untuk mengetahui kandungan senyawa metabolit sekunder dari sutu cuplikan, Alkaloid adalah suatu senyawa yang mengandung satu atau lebih atom Nitrogen yang terbentuk dan biasanya terdapat dalam bentuk gabungan sebagai bagian dari sistem siklik [13]. Di dunia medis, alkaloid digunakan untuk menenangkan saraf pusat, menstimulasi kerja saraf, antibakteri, dan juga untuk terapi anti kanker [14]. Pereaksi Dragendorf merupakan hasil dari campuran bismuth nitrat yang bereaksi dengan kalium iodida sehingga membentuk endapan hitam bismuth (III) iodida yang kemudian melarut dalam kalium iodida berlebih membentuk tetraiodobismuth. Uji alkaloid dengan pereaksi Dragendorf yang positif ditandai dengan adanya endapan coklat yang merupakan kalium alkaloid. Nitrogen pada uji alkaloid dengan pereaksi Dragendorf digunakan untuk membentuk ikatan kovalen koordinasi dengan $\mathrm{K}^{+}$yang merupakan ion logam [15]. Pada pengujian menggunakan pereaksi Dragendorf, sampel daun kering dan daun segar positif mengandung alkaloid.

Flavonoid merupakan golongan senyawa polifenol yang bersifat polar karena memiliki gugus hidroksil dan juga karbonil sehingga flavonoid dapat larut dalam air. oksigen pada gugus karbonilnya akan terprotonasi ketika direaksikan dengan $\mathrm{HCl}$. Hasil reaksinya berupa garam flavilium yang berwarna merah tua. Flavonoid dapat digunakan untuk menghambat pertumbuhan mikroba dengan cara masuk ke dalam sel yang menyebabkan terkoagulasinya protein pada membran sel sehingga mengakibatkan struktur protein rusak [16] [17]. Hasil uji ekstrak daun segar jeruk lemon ini menunjukkan warna merah ungu, hal ini menandakan bahwa ekstrak daun jeruk lemon segar positif mengandung golongan senyawa flavonoid. Namun, pada daun kering menunjukkan hasil yang negatif, hal ini dapat disebabkan oleh kandungan air yang lebih sedikit dalam daun kering sehingga mempengaruhi proses ekstraksi senyawa yang bersifat polar seperti senyawa flavonoid. 
Fenol merupakan zat kristal tak berwarna yang memiliki bau khas, Rumus molekul dari fenol adalah $\mathrm{C}_{6} \mathrm{H}_{5} \mathrm{OH}$ dan strukturnya memiliki gugus hidroksil yang berikatan dengan cincin fenil. Hasil positif fenol ditandai dengan terjadinya perubahan warna menjadi biru kehitaman. Hal ini terjadi karena adanya reaksi antara fenol dengan $\mathrm{FeCl}_{3}$ yang membentuk senyawa kompleks [18]. Hasil uji ekstrak daun kering dan daun segar jeruk lemon ini menunjukkan terbentuknya kompleks berwarna, hal ini menandakan bahwa ekstrak daun jeruk lemon kering dan daun segar positif mengandung golongan senyawa fenol.

Tanin merupakan salah satu jenis senyawa metabolit sekunder yang dihasilkan oleh tumbuhan. Tanin mempunyai berat molekul 5003000 serta mengandung gugus hidroksi fenolik yang memungkinkan terbentuknya ikatan silang yang efektif dengan protein dan molekul-molekul lain seperti asam amino, polisakarida, asam nukleat dan asam lemak [19]. Jika direaksikan dengan besi akan menghasilkan warna yang gelap karena tanin merupakan bagian dari senyawa polifenol [20]. Tanin berfungsi sebagai pelindung diri dari serangan hewan pemakan tumbuhan [21] dan sebagai antibakteri [22].

\section{KESIMPULAN}

Dari ketujuh komponen senyawa fitokimia yang diuji, dapat dilihat bahwa daun kering Citrus $x$ limon positif mengandung senyawa alkaloid, fenol dan tanin. Sedangkan daun segar Citrus $x$ limon positif menunjukkan kandungan senyawa alkaloid, flavonoid, fenol dan tanin.

\section{REFERENSI}

[1] A. W. Nugroho, "Konservasi Kenekaragaman Hayati Melalui Tanaman Obat Dalam Hutan di Indonesia Dengan Teknologi Farmasi: Potensi dan Tantangan," J. Sains dan Kesehat., vol. 1, no. 7, pp. 377-383, 2017.

[2] P. Setyaningrum, E. D., Kartika, R., Simanjuntak, "Uji Skrining Fitokimia dan Uji Aktivitas Antioksidan dari Daun Akasia (Acacia auriculiformkis Benth)," Pros. Semin. Nas. Kim., pp. 94-96, 2017.

[3] M. Fitrah, "Identifikasi Ekstrak Daun Kopasanda (Chromolaena odorata Linn) Terhadap Sel Antiproliferasi Tikus Leukemia L1210," Jf Fik Uinam, vol. 4, no. 3, pp. 99-105, 2016.
[4] H. S. Indriani Y., Mulqie L., "Uji Aktivitas Antibakteri Air Perasan Buah Jeruk Lemon (Citrus limon (L.) Osbeck) dan Madu Hutan Terhadap Propionibacterium acne," Pros. Penelit. Sivitas Akad. Unisba (Kesehatan dan Farm., vol. 2, no. 3, pp. 22-30, 2015.

[5] E. Ahmad, F. M. Y., Katja, D. G., Suryanto, "Uji Fitokimia Ekstrak Kulit Batang Chisocheton sp.(C.DC) Harms Yang Tumbuh di Gunung Soputan Sulawesi Utara," J. IIm. Farm., vol. 7, no. 4, pp. 23-30, 2018.

[6] W. Krisnawan, A. H., Budiono, R., Sari, D. R., Salim, "Potensi Antioksidan Ekstrak Kulit dan Perasan Daging Buah Lemon (Citrus limon) Lokal dan Import," Pros. Semin. Nas., pp. 30-34, 2017.

[7] P. Suja, D., G. Bupesh, N., Rajendiran, V., Mohan, P., Ramasamy, N. S.,Muthiah, A. A., Elizabeth, K., Meenakumari, K., "Phytochemical Screening, Antioxidant, Antibacterial Activities of Citrus Limon and Citrus Linensis Peel Extracts," Int. J. Pharmacogn. Chinese Med., vol. 1, no. 2, p. 000108, 2017.

[8] M. H. Yang, J. S. Wang, J. G. Luo, X. B. Wang, and L. Y. Kong, "Tetranortriterpenoids from Chisocheton paniculatus," J. Nat. Prod., vol. 7, no. 2, pp. 36-43, 2009, doi: 10.1021/np900485t.

[9] Badan POM RI, "Pedoman Teknologi Formulasi Sediaan Berbasis Ekstrak.Volume 2. Jakarta: Direktorat Obat Asli Indonesia, Deputi Bidang Pengawas Obat Tradisional, Kosmetik dan Produk Komplemen," vol. 7, no. 8, pp. 12-16, 2013.

[10] M. . T. Mayasari, U., Laoli, "Karakterisasi Simplisia dan Skrining Fitokimia Daun Jeruk Lemon (Citrus limon (L.) Burm. F.)," J. IImu Biol. dan Terap., vol. 2, no. 1, pp. 7-13, 2018.

[11] A. Tuhuloula, L. Budiyarti, and E. N. Fitriana, "Karakterisasi Pektin dengan Memanfaatkan Limbah Kulit Pisang Menggunakan Metode Ekstraksi," Konversi, vol. 2, no. 1, pp. 21-27, 2013, doi: 10.20527/k.v2i1.123.

[12] H. Halimatussakdiah, U. Amna, and P. Wahyuningsih, "Preliminary Phytochemical Analysis and Larvicidal 
Activity of Edible Fern (Diplazium esculentum (Retz.) Sw.) Extract against Culex," J. Nat., vol. 18, no. 3, pp. 141146, 2018, doi: 10.24815/jn.v0i0.11335.

[13] P. J. Puspita, M. Safithri, and N. P. Sugiharti, "Antibacterial Activities of Sirih Merah (Piper crocatum) Leaf Extracts," Curr. Biochem., vol. 5, no. 3, pp. 1-10, 2019, doi: 10.29244/cb.5.3.1-10.

[14] S. Susilawati and N. C. Chotimah, "Difference of Weight Gain in Baby Mother Given Boiled Of Papaya Fruit," J. Kesehat., vol. 5, no. 1, pp. 34-39, 2019, doi: 10.25047/j-kes.v5i1.36.

[15] R. Nugrahani, Y. Andayani, and A. Hakim, "Skrining Fitokimia dari Ekstrak Buah Buncis (Phaseolus vulgaris L) dalam Sediaan Serbuk," J. Penelit. Pendidik. IPA, vol. 2, no. 1, pp. 96-103, 2016, doi: 10.29303/jppipa.v2i1.38.

[16] M. H. Kemala, D., Hendiani, I., Satari, "Uji Daya Antibakteri Ekstrak Etanol Kulit Buah Manggis (Garciani mangostana L) Terhadap Streptococcus Sanguinis ATCC 10556," Padjajaran J. Dent. Res. Students, vol. 3, no. 1, pp. 1-5, 2019.

[17] M. Syafrida, S. Darmanti, and M. Izzati, "Pengaruh Suhu Pengeringan Terhadap Kadar Air, Kadar Flavonoid dan Aktivitas Antioksidan Daun dan Umbi Rumput Teki (Cyperus rotundus L.)," Bioma Berk. IIm. Biol., vol. 20, no. 1, pp. 44-50, 2018, doi: 10.14710/bioma.20.1.44-50.

[18] S. W. Azizah, Z., zulharmita., wati, "Skrining Fitokimia dan Penetapan Kadar Flavonoid Total Ekstrak Daun Pre (Momordica charantia L.)," J. Farm. Higea, vol. 10, no. 2, pp. 163-172, 2018.

[19] N. Hidayah, "Pemanfaatan Senyawa Metabolit Sekunder Tanaman (Tanin dan Saponin) dalam Mengurangi Emisi Metan Ternak Ruminansia," J. Sain Peternak. Indones., vol. 1, no. 2, pp. 89-98, 2016, doi: 10.31186/jspi.id.11.2.89-98.

[20] H. Nurjannati, M., Winarsi, H., dan Dwiyanti, "Efek Lama Perkecambahan Terhadap Sifat Sensori dari Kadar Protein Terlarut Susu Kecambah Kacang Merah (Sukarah) untuk Remaja Obesitas," J. Gipas, vol. 2, no. 2, pp. 2742, 2018.

[21] dan W. Sarifudin, A., Wardatun, S.,
"Kajian Metode Pengeringan dan Metode Analisis Daun Belimbing Wuluh (Amverrhoa bilimbi L.) Terhadap Kadar Tanin," J. Online Mhs. Bid. Farm., vol. 1, no. 1, pp. 1-9, 2018.

[22] S. Noer and R. D. Pratiwi, "Uji Kualitatif Fitokimia Daun Ruta Angustifola," Fakt. Exacta, vol. 9, no. 3, pp. 200-206, 2016. 